International Journal of Linguistics, Literature and Culture
Available online at https://sloap.org/journals/index.php/ijllc/
Vol. 6, No. 1, January 2020, pages: 62-69
$\begin{aligned} & \text { ISSN: 2455-8028 } \\ & \text { https://doi.org/10.21744/ijllc.v6n1.844 }\end{aligned}$

\title{
The Existence of Māyādanawa Story in Bali
}

I Made Wiradnyana ${ }^{a}$

Article history:

Submitted: 27 November 2019

Revised: 09 December 2019

Accepted: 18 January 2020

\section{Keywords:}

holy;

Māyādanawa;

myth;

religious;

story;

\begin{abstract}
The research was intended to explore the existence of Māyādanawa story in Bali. A researcher is a key instrument in qualitative research, in addition to the researcher doing more research in the field. The primary data source of this study is the speech data, the instruments used in the study include (1) recording aids in the form of a recording tape to document Māyādanawa storytelling from informants; (2) oral data notes to anticipate loss or obscurity of data from the results of the recording; (3) cameras to document religious aspects related to the Māyādanawa story, unlike, the palinggih relics in the Tirta Empul Tampaksiring temple, the Māyādanawa tunnel/cave and the ritual activities at the holy sites and other related activities. Before conducting data collection, the researcher established good relations with the local community. Data collection was obtained using the methods of participatory observation, in-depth interviews and documentation. Data collection can be done by naturalistic observation and in-depth interviews or open-ended (or ethnographic in-depth interviews).
\end{abstract}

International journal of linguistics, literature and culture (C) 2020. This is an open access article under the CC BY-NC-ND license (https://creativecommons.org/licenses/by-nc-nd/4.0/).

Corresponding author:

I Made Wiradnyana,

Institut Hindu Dharma Negeri, Denpasar, Indonesia.

Email address: wiradnyanakedisan@yahoo.com

${ }^{a}$ Institut Hindu Dharma Negeri, Denpasar, Indonesia 


\section{Introduction}

Research on myths is interesting because myths are seen as a result of the construction of a society's culture. It is used as a truth in the community of the myth owner without knowing the meaning behind the myth. Therefore, it is very necessary to do research on myths in order to reveal the way of thinking contained behind the myths in a story. The Bali island, namely the Gods Island or temple thousands island has hundreds of folklore whose ideology is sourced from the Veda as a Hindu sacred library baboon. Folklore is one form of regional cultural expression that wants to embody (manifest) the Vedas teachings in a real way. The existence of folklore as said by Guvaherath et al. (2019), is a cultural phenomenon and a picture of the creativity of thinking of a community as outlined orally. Thus, it becomes a universal source of oral literature in people's lives. As a product of public culture, oral literature in its various forms can be found in almost all places in the world. Oral literature is generally created as a response and the thinking result of the social system.

Mishra (2016), described folklore is communal (shared community), local (emerges and develops in certain places), and informal (not passed down through formal education). It's oral, communal, and informal nature results in the authenticity of oral literature. It is difficult to maintain for a long time. The change cannot be avoided over time and their spread becomes more widespread. The stories of the people may become more and more supplemented with additional stories and vice versa. They can be reduced the weight of the original story in order to be more entertaining, more frightening, more astonishing, more fantastic, and so on. Nevertheless, the core of the storyline will always be maintained by a community.

Balinese folklore in various forms is interesting to be discussed. One of the most famous folk tales in Bali is the myth of Māyādanawa. It is one of the oral traditions that grew and developed in Balinese society. Oral traditions in Balinese culture can be traced through archaeological data and linguistic data. It is essentially sourced from Austronesian culture. It is estimated to have penetrated Bali around 5000 to 4000 years ago (Ardika, 1997). General characteristics of tradition in Austronesian culture include the habit of farming, skill in making a boat, a very strong artistic tradition. It has emerged since prehistoric times and developed to the present, worship of ancestors and the habit of determining seniority (birth order) in kinship (Bellwood, 1995; Ardika, 1997). If having seen through Hindu libraries about historical stories which in Hinduism are called itihasa. The historical stories contained in the Mahabharata literature, then become stories. It also stated in the Ramayana library. Bali as the island of a thousand temples and Bali as the Island of the Gods, the Balinese folklore or Balinese oral literature is very likely influenced by both or one of the great stories.

Oral tradition tells the myth of the Māyādanawa story can be understood as a form of inheritance or the transmission of norms and customs that apply in Bali. They are combined with a variety of human actions and promoted throughout. People who make things with their traditions, people also accept them, reject them or change them. That is why the myth underwent a complex transformation. The complexity of the Māyādanawa myth can be traced from various types of sources in ancient Bali, namely the period between the $9^{\text {th }}$ century and the end of the $17^{\text {th }}$ century. The sources are in the form of inscriptions, archeological relics, and written texts in palms that refer to events. It has occurred in various time periods in the past. Kartodirdjo \& Abdullah (1986), mentioned in some important sources about older Bali. They were composed perhaps in the second half of the $18^{\text {th }}$ century. It was made in reference to an Old Javanese text called usana bali by Dangyang Nirartha.

The Māyādanawa story is seen as a myth. This can be seen in a variety of interests, namely interests in the study of literary discourse, religious studies (especially on theological aspects), anthropological studies and the interests of other studies. It involves the view of human cosmology as a supporter of culture. The religion of a society is a set of institutionalized rituals. They are identified with tradition and express and or produce sacred sentiments directed at the divine or trans-divine focus. It is visible in the context of the human phenomenological environment. It is partially described with myths and doctrines (Smart, 2000). This is confirmed by Baal (1987), explained the myth (including Māyādanawa) is the framework of a system of religious things, which in the past or in the present. They were acting as religious truth. This containment gives context to continue recognizing a story as a myth, as well as, dialectical religious truth. It still plays a role as a religious truth.

\section{Literature review}

Hutomo (1999), examined the legend Maling Kentiri is quite well known in the Blora community, Central Java. Kentiri is believed by the people of Blora as 'Ratu Adil', a figure who lifts people out of the poverty and turmoil of

Wiradnyana, I. M. (2020). The existence of Māyādanawa story in Bali. International Journal of Linguistics, Literature and Culture, 6(1), 62-69. https://doi.org/10.21744/ijllc.v6n1.844 
the times. It was found the legend of Maling Kentiri still alive in the community by comparing the oral and written versions, even though it had been 'battered' because of the intervention of certain people who gave a new meaning to the character. The community believes in the truth of the Kentaling figure because the character, through the narrator, leaves a 'historical witness' in the form of place's name and villages as well as objects claimed by the character. Unlike, the story of Māyādanawa, the characters actually experience a dynamic and an existence. It is similar to the legend of the Kentiri. Even though, in the midst of the Tampaksiring or Balinese society in general, various versions of the Māyādanawa story appear very thick with diverse social, cultural and political backgrounds.

Soedjijono (2009), examined Reyog Ponorogo. Archeological studies involve three disciplines namely anthropology, psychology, and literary criticism. The focus was on psychology and literary criticism. It was described the three archetypal elements in the Reyog Ponorogo legend namely the archetypal meaning of the character, the situation or archetypal event and the archetypal image. Danandjaja (1984), mentioned using a modern folklore approach. The modern folklore approach was not only examined his lore or oral tradition but also his folk or collective community. This study of the Māyādanawa story also accommodates Sutarto's approach. The research of the Māyādanawa story not only examines the Māyādanawa story as oral literature but also examines the society in which the legend lives, especially with regard to the way the legend is functioned and interpreted by the community. Kusuma (2002), stated myth is one type of oral literature found in almost every region in Indonesia. It is often used as a guide for carrying out religious ceremonies. This fact shows how important the meaning and function of myth. It is for people's lives. Finegan (1978), stated to fully understand a myth. It is not enough to only be understood through the interpretation of its words, but also the social context of the myth which needs to receive deep attention.

\section{Materials and Methods}

In determining the location of research, the author refers to the characteristics of the study area. Therefore, the research object can be determined is a representation of the Bali region. It is related to the problem under study. On prioritizing the characteristics of the study area, it is expected to minimize errors, especially in determining the location of the research determined purposively. Many informants in qualitative research do not determine whether or not accurate research (Basrowi, 2002). Endraswara (2009), mentioned there are two kinds of informants in oral literary research, namely key informants and ordinary informants. Key informants are figures who play an important role in oral literature (for example, masterminds, community leaders, traditional and religious elites, elders and other actors). Community leaders usually play the role of key informants. The key informant is usually a breed of the heir to oral literature, while the regular informant may also be a connoisseur or audience of oral literature, but his role remains urgent.

The study of the Māyādanawa (oral literature) story has a problem which is quite typical namely the tension between oral and written data. If it is based on the nature of oral literature. Data that must be used in research are purely oral data. Over time, orality seems to have mixed with written culture. The between oral and written, in research Māyādanawa stories, including oral literature are often difficult to monitor. The between stories are spoken and stories were written there will always be tension. They are always moving continuously from verbal to written and vice versa. The ability of researchers to actually retrieve data is important in this kind of research. Oral and written data should support each other in story research (Endraswara, 2009). A researcher is a key instrument in qualitative research, in addition to the researcher doing more research in the field. The primary data source of this study is the speech data, the instruments used in the study include (1) recording aids in the form of a recording tape to document Māyādanawa storytelling from informants; (2) oral data notes to anticipate loss or obscurity of data from the results of the recording; (3) cameras to document religious aspects related to the Māyādanawa story, unlike, the palinggih relics in the Tirta Empul Tampaksiring temple, the Māyādanawa tunnel/cave and the ritual activities at the holy sites and other related activities. Before conducting data collection, the researcher established good relations with the local community. Data collection was obtained using the methods of participatory observation, in-depth interviews and documentation. Endraswara (2003), data collection can be done by naturalistic observation and indepth interviews or open-ended (or ethnographic in-depth interviews). 


\section{Results and Discussions}

A belief in supernatural forces has attracted human attention, especially in matters relating to daily life. This is reflected in human's belief in natural events beyond the reach of human power, such as births, deaths, the course of the universe, the rotation of seasons, natural disasters, and so on. Behind the incident, humans believe there is an influence from extraordinary powers, full of mystery, whereas, the human cannot prove with their minds. Thus, to see an object or event that people experience tends to connect it with what has happened and witnessed before. One of the special human characteristics is to try to relive past experiences and put themselves in the future. Past, present, and future is a network of events (Daeng, 1991). The media is to re-prove past experience gained in the form of hereditary heritage from ancestors is through the form of myth. Levi-Strauus (1997), the myth also exists in two times at once, namely, time can be reversed and time that cannot be reversed. This is seen from the fact myths always refer to events that occurred in the past, such as the words 'supposedly long ago' 'once upon a time in the past'. They are always found in every opening of a myth. The typical patterns of myths are features make myths can remain relevant and operational in the current context. Certain patterns expressed by myths, which are described by myths are timeless. These patterns explain what will happen in the past, however, the same time can also explain what is happening now, and what will happen in the future.

\subsection{Revealing myth of Māyādanawa story in Bali}

The life's view of Hindu community generally in Bali is based on the customs (traditions) of religion, beliefs, and culture. This view basically emphasizes harmony and balance, both towards oneself, fellow nature and with God (Tri Hita Karana). Unlike, the attitude of life is regulated in various rules such as rules, etiquette/manners, which regulate harmony in society, worship regulations that govern formal relations with God, and moral rules that emphasize moral attitudes and actions. The socio-cultural perspective $21^{\text {st }}$ century the pressures influence Balinese cultural objects are economics, technology, and ethics, the essence. First, the development of a technological system is likely to continue and will influence aesthetic decisions. It will develop towards a complex system. Second, the pressure of a free market economy has changed the postmodern human concept of time, self, individual, family, society, space, nation and state. Third, moral pressure concerning humanity and the environment continues to increase, including pressure on cultural objects (Pilliang, 1999). A new civilization is growing in human life. This civilization brought a new style in family life, changed the way of work, how to make love and way of life, brought a new economic order, new conflicts and above all changed human consciousness (Toffler, 1990).

The present context as described above seems to have 'swallowed' something involved tradition. Thus, the question of whether oral tradition still has a place in the context of contemporary culture. Wherein humans have existed in the context of modernization and even postmodern. Tracing the present context of this tradition is actually intended in this study. The scope and depth of the transformation of the Māyādanawa story in the form of art, literature, and religion. It can be understood the narrative or mythical dimension of religion is nothing but the face of Hinduism in the form of language. They can be found in stories about events, places, figures, which describe purity, mystery, strength outside of human beings in a cosmic order. The myth in the Māyādanawa story can be seen in two interests, namely the interests of Hindu religious studies, as well as the interests of Anthropological studies. Due to it involves the view of human cosmology as a supporter of culture itself. The religion of a group (culture) is a set of institutionalized rituals that are identified with tradition and which express and/or produce sacred sentiments directed at the divine or trans-divine focus. It appears in the context of the human phenomenological environment and at least partially depicted with myth or myth and doctrine (Smart, 2000).

Based on the understanding of myth as the object of religious and anthropological studies, it is clear the myths in the Māyādanawa story still have relevance to the present context to understand the religious meaning and cultural views of society towards the universe. At least the Māyādanawa story has a 'universal logic' that deserves scrutiny to identify the character of a particular cultural mentality and religious religiosity. Van Baal (1987), stated myths as a framework for a system of religious things. They were past or in the present have or are acting as religious truths. This definition gives contexting to continue to recognize a story as a myth. It is currently no longer accepted as religious truth, but in the past, it still acts as religious truth.

Wiradnyana, I. M. (2020). The existence of Māyādanawa story in Bali. International Journal of Linguistics, Literature and Culture, 6(1), 62-69. https://doi.org/10.21744/ijllc.v6n1.844 


\subsection{Cultural facts on Māyādanawa story}

This analysis is the exploration of the core (substance) the myth oral tradition of Māyādanawa story can be examined from the narrative aspect, in the sense. The language expressions or words written in the story can show cultural facts as explained by Edi Sedyawati (1995). Cultural facts unlike the genealogical system, cosmology and cosmogony, history, philosophy, ethics, morals, systems of knowledge and language rules, are part of people's behavior and way of thinking as the substance of study.

a) Regional integration in myth of Māyādanawa story

A series of areas became the myth cruising point of Māyādanawa story, apparently gave rise to patterns of regional names along the Petanu Watershed and along the Pakerisan Watershed. The study of the integration of the region formed, the researcher described integrated into the perspective of oral tradition data (Māyādanawa story) and in written tradition (Usana Bali). Discussing the formation of regional integration along the Petanu watershed is reminded of Māyādanawa story once ruled in Bali and very arbitrary actions. One of the behaviors that came out of the path of dharma was to forbid Balinese people from offering offerings to the Gods. Due to the Gods to be angry, so the Gods agreed to storm Māyādanawa. Māyādanawa would be attacked immediately prepare a warrior with Patih Kala Wong. Troops were preparing to head towards the northeast of Bedahulu and finally between Lord Indra's warrior and Māyādanawa's warrior somewhere, resulting in war. The great war resulted in many casualties on both sides, especially on the side of Māyādanawa. The place where the fighting took place eventually became a village named Patemon Village which means the place of the battle.

b) Cosmological orientation center in myth story Māyādanawa

Humans as cultural creatures who live in a society essentially support a culture. Each has its own uniqueness. This culture arranges and also influences the lives of the people concerned in dealing with their environment, both towards the social, cultural, natural and physical environment. The Balinese who inhabit in Bali Island is ethnic groups bound by an awareness of their cultural unity. Such unitary awareness is further strengthened by the existence of the same language and the existence of Hinduism. They have long been integrated into Balinese culture. Despite this awareness, Balinese culture essentially manifests many local variations and differences (Suyasa et al., 2016). This variation does not only apply between districts/cities in Bali but applies between villages in a district. It is often referred to as a form of sima. Sima is a social order that is respected by those who have traditions especially in rural areas. The Balinese in their social and cultural life structure has special characteristics as a community called Desa Pakraman.

A belief system is closely related to traditional values that live in Bali. It is a belief system of dualistic classification, (binary opposition). The system of classifying the universe (macrocosm) is over two baggage categories and so on. This classification reflects the religious nature of society and the extent of its role in the pattern of their actions as citizens of a community (Geriya, 1981). The categories in the view of Hindu cosmology in Bali gave rise to the holy direction. It refers to the concept of luan-teben (upstreamdownstream). As luanan (upstream) is a mountain (highest place) which in Balinese is called Kaja (north), contrasted with teben (downstream). Segara (sea) positioned Kelod (south) direction. Kaja direction which is seen as the main direction and purified, then identified with the direction to the mountain or up. The direction to the mountain or up is opposed to the direction of the kelod which means the direction of the sea or downward. This forms a dualistic pair, kaja-kelod which is identified with the gunung-segara (mountain-sea) opposition.

c) Religious culture in myth story Māyādanawa

The story of Māyādanawa obtained religious culture namely Galungan holy day celebrations, malukat traditions and art products such as painting, crafts, and art performances. The emergence of Galungan holy day celebrations, e.g., penjor is often associated with the myth of Māyādanawa. Apart from the disagreement about the mythical relationship of Māyādanawa with Galungan, for some Balinese people and a number of writers assume. The festival day of Galungan is done after Lord Indra successfully won the battle against Māyādanawa. Lord Indra was seen as the bearer of dharma and vice versa Māyādanawa was considered the bearer of adharma. Therefore, Galungan celebration is seen as a day of dharma victory against adharma. To strengthen the celebration of victory, the residents installed a Galungan penjor in the house's yard. Penjor has a function, among others, as a 'flag' to declare victory. In addition to functioning as a religious function that is as a symbol of Mount Agung as worship of Lord Shiva. For this reason, Penjor Galungan always contains a 
'sanggah' the offering's place. Having a religious function, penjor also has an aesthetic function. It is to beautify the scenery and create a religious atmosphere.

\subsection{Māyādanawa trail in Bali}

The research locations were carried out in all regions of Bali, but to get primary data, it was mostly done in Gianyar Regency. This was done because Māyādanawa traces were mostly found in Gianyar Regency. Apart from in Gianyar Regency, there are estimated traces of the Māyādanawa story also found in the Regency of Bangli and Karangasem. The full description can be explained as follows.

a) Māyādanawa trail in Gianyar Regency

This can be traced both through stories (oral and written) and archeological remains. According to Jero Mangku Dewa Gede Wenten (interviewed on 3 February 2017) Māyādanawa was a king who ruled in Bedahulu. He was the son of King Çri Jayapangus from the results of his marriage to Dewi Danu. Before Māyādanawa was crowned king in Bali, there was already a throne of a king named Detya Karnapati with Abiseka Çri Jayapangus who had a palace in Balingkang. After King Jayapangus died, it was then Bali was led by Māyādanawa as a king. While turning the wheel of government in Bedahulu, Māyādanawa was accompanied by a Patih named Kala Wong. The administrative center is no longer in Balingkang (Bangli) but it is located in Pejeng (Gianyar Regency). At the beginning of the Māyādanawa government, the condition of the Bali Island was not much different from the reign of Çri Jayapangus who had a palace in Balingkang. But lately, he's arrogant, anarchist and arbitrary attitude caused the situation to turn into chaos. Thus, he had to die by Indra.

c) Māyādanawa trail in Bangli Regency

This can be seen in several place names and stories that tell the ancestors of the Māyādanawa character. In this district, there is a temple named Pura Dalem Balingkang located in Pinggan Village, Kintamani Subdistrict. This temple has a history and originates from various versions, which connect the existence of king Jaya Pangus with a princess from China. The building of Pura Dalem Balingkang was previously a palace. As a palace, this building has a fortress that fences it has an important function to protect its presence from enemy attacks, the natural wall of the hills that surrounds Mount Batur. There is worship with a symbol of Chinese coins (uang kepeng) large in the northeast corner as a linggih or stana Ratu Ayu Mas Subandar, who during her life was a royal consort from China named Kang Cing Wie. Pelinggih is related to wish luck. Based on that story, there has been acculturation of Hindu culture with Buddhism from the time of the ancestors of Ancient Bali, including cultural heritage. It is related to the origin or history of the existence of Dalem Balingkang. Balingkang Temple is a number of temples in Bali also worshiped for ethnic Chinese such as the pagoda or kongco form, the use of Chinese money (pis bolong) for the ceremonial yadnya equipment of Hindus and phallus in the form of barong land. Dalem Balingkang temple can be seen in Figure 1.

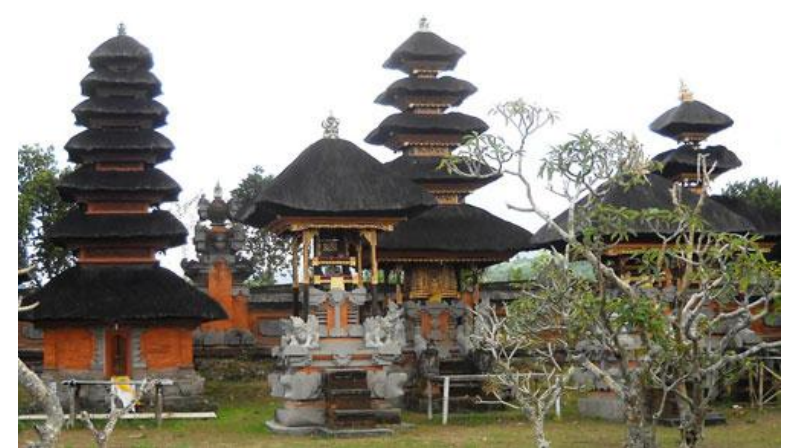

Figure 1. Dalem Balingkang Temple in Kintamani, Bangli

c) Māyādanawa trail in Karangasem Regency

This can be seen in the names of the places and figures of the people involved in the story. The name of the place is Besakih Temple. In the story, both oral and written, Besakih Temple is stated to be a place of worship for several gods such as Mahadeva, Pasupati, Shiva and so on. The worship at Besakih was not favored by

Wiradnyana, I. M. (2020). The existence of Māyādanawa story in Bali. International Journal of Linguistics, Literature and Culture, 6(1), 62-69. https://doi.org/10.21744/ijllc.v6n1.844 
Māyādanawa. The king forbade residents to make offerings to the gods at Besakih, because according to Māyādanawa, the more suitable worship was himself. Then, one of the community leaders who fought against Māyādanawa was Mpu Sangkulputih. This clergyman was told as another name for Arya Bang Manik Angkeran when he was still a walaka.

d) The future on Māyādanawa story in Bali

Māyādanawa in Bali in various forms will remain sustainable in Bali. It is caused by various factors strongly support sustainability. The existence of Galungan-Kuningan day always reminds Māyādanawa story. That is due to the Māyādanawa story is always used as a philosophical basis for the Galungan-Kuningan day. Later, in the context of Nyepi festival day, there is a tradition of the ogoh-ogoh parade held on Pengerupukan Day. Many Hindus make ogoh-ogoh resemble giants and are named Māyādanawa. The existence of ogoh-ogoh is a medium for the preservation of Māyādanawa in this area. Likewise in other art forms, such as painting, performance art (drama gongs, dramatari, ballet, shadow puppets, legong) Māyādanawa story is often raised as themes. These various art forms are the confirmation of the Māyādanawa story. Apart from that version, many people view Barong Landung is closely related to Māyādanawa story. Thus, as long as the Barong Landung is sustainable, the future of the Māyādanawa story will never disappear. It can be seen in the following Figure 2.

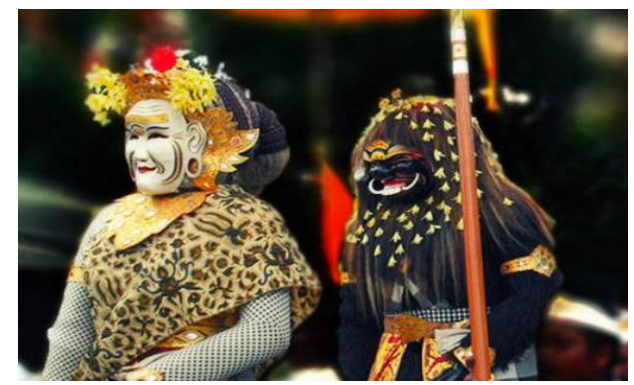

Figure 2. Barong Landung Figure

(left: Jero Luh duplicated Khang Cing Wie and right: duplicated King Jayapangus)

\section{Conclusion}

The story of Māyādanawa obtained religious culture namely Galungan holy day celebrations, malukat traditions and art products such as painting, crafts, and art performances. The emergence of Galungan holy day celebrations, e.g., penjor is often associated with the myth of Māyādanawa. Apart from the disagreement about the mythical relationship of Māyādanawa with Galungan, for some Balinese people and a number of writers assume. The festival day of Galungan is done after Lord Indra successfully won the battle against Māyādanawa. Lord Indra was seen as the bearer of dharma and vice versa Māyādanawa was considered the bearer of adharma. Therefore, Galungan day is seen as a day of dharma victory against adharma. To strengthen the celebration of victory, the residents installed a Galungan penjor in the house's yard. Penjor has a function, among others, as a 'flag' to declare victory. In addition to functioning as a religious function that is as a symbol of Mount Agung as worship of Lord Shiva. For this reason, Penjor Galungan always contains a 'sanggah' the offering's place. Having a religious function, penjor also has an aesthetic function. It is to beautify the scenery and create a religious atmosphere.

\section{Conflict of interest statement}

The author declared that he have no competing interest.

\section{Statement of authorship}

The author have a responsibility for the conception and design of the study. The author have approved the final article.

Acknowledgments

I am grateful to two anonymous reviewers for their valuable comments on the earlier version of this paper. 


\section{References}

Ardika, I. W. (1977). Bali dalam sentuhan Budaya Global pada awal abad Masehi. Dalam Dinamika Kebudayaan Bali. Denpasar: Upada Sastra.

Basrowi, S. (2002). Metode Penelitian kualitatif perspektif mikro. Surabaya: Insan Cendekian.

Bellwood, P. (1995). Austronesian prehistory in Southeast Asia: homeland, expansion and transformation (pp. 103120). Canberra: ANU E Press.

Daeng, H. (1991). Manusia, Mitos dan Simbol. Majalah Basis, 40.

Danandjaja, J. (1984). Folklor Indonesia: ilmu gosip, dongeng, dan lain lain. Grafiti Pers.

Endraswara, S. (2003). Metodologi Penelitian Sastra: Epistemologi, Model. Teori, dan Aplikasi. Yogyakarta: Pustaka Widyatama.

Finegan, T. A. (1978). The measurement, behavior, and classification of discouraged workers (Vol. 12). National Commission on Employment and Unemployment Statistics.

Geriya, I Wayan. 2009. Transformasi Kebudayaan Bali Memasuki Abad XXI. Surabaya: Paramita

Geriya, I. W. (1981). Sistem Kesatuan Hidup Setempat Daerah Bali. Departemen Pendidikan dan Kebudayaan Proyek Inventarisasi dan Dokumentasi Kebudayaan Daerah Bali, Denpasar.

Guvaherath, K., Mainatikau, E., \& Casanne, E. (2019). Social rights on hindu religion and untouchability towards politics and law. International Journal of Social Sciences and Humanities, 3(1), 193-202. https://doi.org/10.29332/ijssh.v3n1.335

Hutomo, S. S. (1999). Filologi lisan dalam kaitan pembentukan wacana kebudayaan. Asosiasi Tradisi Lisan $(\mathrm{ATL})=[$ Oral Tradition Association (OTA)].

Kartodirdjo, S., \& Abdullah, T. (1986). Papers of the Fourth Indonesian-Dutch History Conference, Yogyakarta, 2429 July 1983. In Indonesian-Dutch History Conference 1983: Yogyakarta, Indonesia). Gadjah Mada University Press.

Kusuma, W. I. N. (2002). Mitos Bake di Desa Suana Nusa Penida. Denpasar. TP.

Levi-Strauss, C. (1997). Mitos Dukun dan Sihir. Terjemahan Drs. Agus Cremers, SVC dan Drs. De Santoso Johanes. Yogyakarta: Kanisius.

Mishra, S. K. (2016). The paradigm of religious evolution:the transformation of rudra to pashupata. International Journal of Linguistics, Literature and Culture, 2(3), 28-34.

Piliang, Y. A. (1999). Hiper-Realitas Kebudayaan: Semiotika, Estetika, Posmodernisme. Yogyakarta: Penerbit LKiS.

Sedyawati, E. (1995). Kedudukan Tradisi Lisan dan Ilmu-Ilmu Sosial dan Budayall. Makalah Semiloka Tradisi Lisan Nusantara, 1-21.

Smart, N. (2000). Worldviews: Crosscultural explorations of human beliefs (p. 176). Prentice Hall.

Soedjijono, H. (2009). Kajian arketipal legenda reyog ponorogo. Bahasa dan Seni, 34(1).

Suwardi, E. (2009). Metodologi Penelitian Folklor: Konsep, Teori dan Aplikasi. Yogyakarta: Medpress.

Suyasa, I. M., Kusuma, I. N. W., \& Suarka, I. N. (2016). Revealing the religious meaning of bakayat sasak oral-text. International Journal of Linguistics, Literature and Culture, 2(4), 122-128.

Toffler, A. (1990). Powershift: knowledge. Wealth and Violence at the Edge of the 21st Century.

Van Baal, J. (1987). Sejarah Pertumbuhan Teori Antropologi Budaya; Hingga Dekade 1970, diterjemahkan oleh J. Piry, Pengantar Selo Soemardjan, Jilid I Jakarta: Gramedia.

\section{Biography of Author}

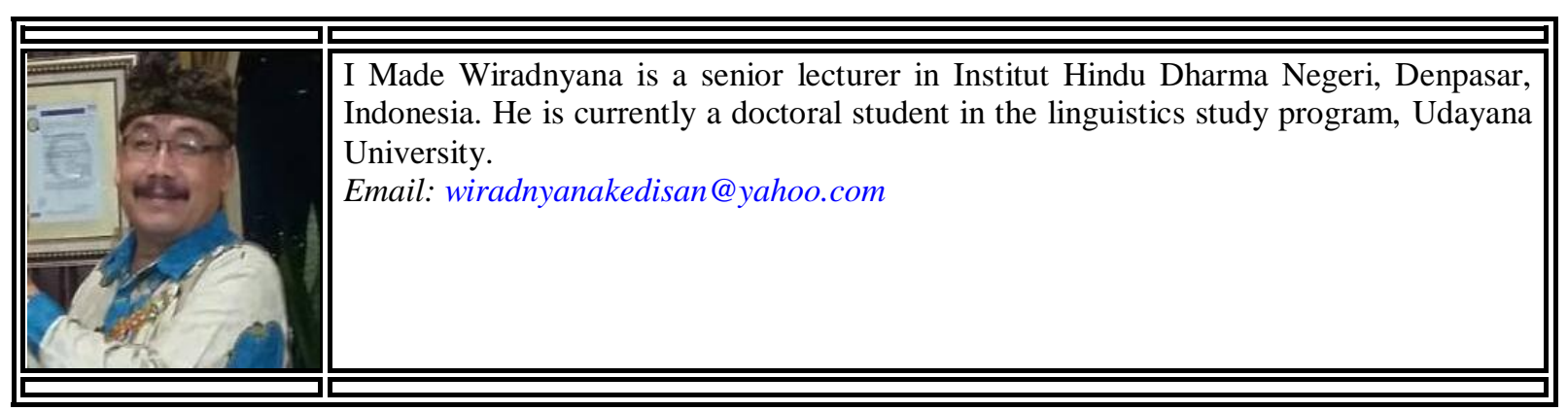

Wiradnyana, I. M. (2020). The existence of Māyādanawa story in Bali. International Journal of Linguistics, Literature and Culture, 6(1), 62-69. https://doi.org/10.21744/ijllc.v6n1.844 